\title{
Strategies Used by Saudi EFL Students to Determine the Meaning of English Words
}

\author{
Abdallah Ahmad Baniabdelrahman ${ }^{1} \&$ Yousif Al-shumaimeri ${ }^{1}$ \\ ${ }^{1}$ College of Education, King Saud University, Saudi Arabia \\ Correspondence: Abdallah Ahmad Baniabdelrahman, College of Education, King Saud University, Saudi Arabia. \\ E-mail: Baniabdelrahman@gmail.com
}

Received: September 30, 2013 Accepted: October 29, 2013 Online Published: December 5, 2013

doi:10.5539/elt.v7n1p75 URL: http://dx.doi.org/10.5539/elt.v7n1p75

\begin{abstract}
This study investigated the strategies which first-year Saudi university EFL students used to derive the meaning of unfamiliar words while reading English texts. Using cluster sampling method, participants chosen to be included in the study consisted of six male and six female classes (120 male and 120 female students) of the preparatory year deanship students at King Saud University, 2009-2010. Following the administration of a vocabulary test as the instrument, descriptive statistics and ANOVA tests were used to analyze the collected data. Results revealed that the students were weak in using the right strategies in guessing the meaning of unknown vocabulary. The use of a combination of two or more strategies was found to result in a better correct guessing rate, but few students tended to use this technique. The results support the importance of practical training in when and how to use various strategies: students need to be given regular practice in order to learn how to use them most effectively. Highlighting the main strategies which students use to correctly derive the meaning of words, the findings indicate EFL teachers should train their students in the use of a variety of strategies for guessing the meaning of unfamiliar words.
\end{abstract}

Keywords: EFL, vocabulary, learning strategies, vocabulary learning strategies

\section{Introduction}

Vocabulary learning is essential to the development of language skills; and in order to acquire the language skills, teachers need to help students with developing their vocabulary knowledge (Mart, 2012).

Word learning/teaching is a complicated process. It requires giving learners a variety of opportunities to connect new words to related words, analyze word structure, understand multiple meanings, and use words actively in authentic ways. Teaching vocabulary is one of the most important challenges that teachers face as the mastery of a basic vocabulary (both active and passive) is very important to students of any language. Vocabulary knowledge has the most important influence on reading comprehension (Bromley, 2007; Allington, 2006; and Nation, 1993). Psychometric studies suggest that vocabulary is a central factor in reading ability (Scott, 2001) and vocabulary knowledge plays a critical role in people's lives and future possibilities (Beck, Mackeon \& Kucan, 2002). The interaction between vocabulary knowledge and background knowledge activates reading comprehension (Bernhardt \& Kamil, 1995). Edwards states that (2009) students will see how the new item (a new word) works grammatically and the context will help make the item more memorable and aid retention.

There is a strong relationship between reading comprehension and vocabulary knowledge. They state that "no text comprehension is possible, either in one's native language or in a foreign language, without understanding the text's vocabulary" (Laufer, 1997: 20). Good and fluent readers recognize and understand many words, and they read more quickly and easily than those with smaller vocabularies (Allington, 2006). Vocabulary skills are good predictors of academic success. Learners need to have an in-depth understanding of the meaning of words to communicate effectively, as well as to make sense of what they read (Leikin \& Deacon, 2007). Furthermore, the major hurdle for ESL/EFL learners is the lack of sufficient vocabulary in English, in addition to the lack of appropriate reading strategies (Haynes \& Baker, 1993).

The vocabulary size is important for ESL/EFL learners. Unless they have knowledge of at least 3,000 of the most frequently used words, they cannot achieve fluency of access (Nation, 1993; Ridgway, 1997).

Both the methods of teaching vocabulary and the strategies students use in deriving the meaning of unfamiliar 
words affect their vocabulary building process. In the past, the focus was on memorization of a certain number of words every day by repetition inside and outside the classroom. With this technique the new words were retained as isolated vocables, had few associations, and hence could be recalled only as isolated words and with a maximum of effort. The teaching of vocabulary was something passive and lifeless. "There is a great divide between what we know about vocabulary instruction and what we (often, still) do" (Greenwood, 2004: 28). The use of a suitable strategy or strategies of word learning has a great positive effect on putting the new words into use (Nash and Snowling, 2006). Teaching vocabulary well is a key aspect of developing engaged and successful readers (Bromley, 2007). The more children participate in rich oral and reading vocabulary experiences, the greater their vocabulary knowledge and reading comprehension (Lynch-Brown, 2002).

Although each teacher has a different style of teaching that they believe provides the most effective way to help students grasp the desired learning concepts, there is one point teachers agree on: teaching vocabulary to children needs to be an active process that engages students in entertaining activities and helps them build a bridge between already known vocabulary and new vocabulary (Smith, 2003; Thornbury, 2006). The new words need to be integrated into the learners' prior knowledge, repeated in multiple contexts and used in meaningful ways (Aihara, et al., 2000). Although interest in second/foreign language vocabulary learning has grown steadily in the last decade, resulting in a growing number of studies and research articles leading to an improvement in vocabulary learning, there are still many issues that need to be studied and investigated. One of these is the question of the strategies of learning and teaching that should be followed in teaching L2 vocabulary.

It could be more useful to teach students strategies to guess the meanings of unfamiliar words than to spend a great deal of time on teaching them as unconnected items. Learners do not need to remember and recall all the words in a passage, as they can guess the meanings through morphological, syntactic, and discourse information in the text (Irvin, 1990). Thornbury (2002) argues that guessing from context is probably one of the most useful skills learners can acquire and apply both inside and outside the classroom. What's more, it seems to be one that can be taught and implemented relatively easily. It is also one that we all already use perhaps unconsciously when reading and listening in our mother tongue.

Teachers can teach their students the following strategies: guessing word meaning from context; teaching mnemonic techniques; and teaching students to analyze words through their component parts (Nation, 1990). Mnemonic techniques are techniques used by students to remember the meanings of words by correlating the word with something they know which could be in their mother tongue and generating a picture of the association.

Coady (1995) gave several suggestions about teaching vocabulary to non-native speakers of English. First, there is no need for teachers to devote much time to direct vocabulary teaching in the classroom. Second, students learn vocabulary through reading but they need to be trained to use strategies for deriving the meanings of unfamiliar words from context. Third, ESL/EFL students should be taught high frequency words. Fourth, a variety of activities should be used in the classroom to help students understand new words (Nation, 1994). Fifth, narrow reading (reading the same topic in different texts) could be helpful (Leikin \& Deacon, 2007).

\section{Statement of the Problem}

First-year EFL students in Saudi Arabia face difficulties in reading English material which might be due to insufficient vocabulary they learn at school and the strategies they use in guessing the meaning of unfamiliar words.. Although the English language curriculum in Saudi Arabian schools concentrates on using the communicative approach, vocabulary learning in most cases still takes place through looking up unknown words in a dictionary or giving their meaning in Arabic (the mother tongue).

While deriving meanings from context is generally considered helpful, contradictory views exist among researchers: some found it useful (Bueno Gonzalez, 1998), others found that context clues were not reliable sources for learning new words. The ability to infer the meanings of unknown words encountered while reading plays an important role in learners' L2 word-knowledge development. Despite numerous findings reported on word-meaning inference, how learners develop this ability is still unclear (Hamada, 2009).

\subsection{Purposes and Questions of the Study}

This study investigated the strategies which the first-year university students used to derive the meanings of unfamiliar words by seeking to answer the following questions:

1) How proficient are first-year Saudi university EFL students in guessing unfamiliar word meanings?

2) What strategies do first-year Saudi university EFL students use to derive unfamiliar word meanings? 
3) What strategies do first-year Saudi university EFL students use which result in correct derivation of unfamiliar word meanings?

4) Does first-year Saudi university EFL students' ability to derive the meaning of unfamiliar words vary with respect to their gender and their language proficiency?

\subsection{Significance of the Study}

The results of this study should provide suggestions for improving the teaching of English as a foreign language. They should help EFL teachers in allotting time to teach students the strategies they need to deal with new words. Moreover, the results could contribute to the body of knowledge on different methods of teaching and strategies used by students in deriving the meanings of unfamiliar words.

Most of the studies conducted on the strategies students use to determine the meaning of unfamiliar words have been carried out in western countries where students are either native speakers or non-native speakers who have lived for a long period of time in an environment which is different from the context in which this study has been conducted.

\section{Literature Review}

Nation (1994) recommends that the activities of vocabulary teaching to non-native speakers should include five stages: providing students with texts that include new (unknown) words; engaging students in activities to negotiate the definitions of those words; designing enriching activities to help students understand the parts of speech; practicing the strategies to guess the meaning of words in context; and helping students to become fluent with the acquired words through using them in different contexts.

According to Bromley (2007), teaching vocabulary well is a key aspect of developing engaged and successful readers. For Greene and Lynch-Brown (2002), the more children participate in rich oral and reading vocabulary experiences, the greater their vocabulary knowledge and reading comprehension. Bromley lists nine things that teachers should know and remember about words and word learning to be effective teachers of vocabulary.

1) English is a huge and unique collection of words.

2) The rules of English are simple and consistent compared to other languages.

3) Language proficiency grows from oral competence to written competence.

4) Words are learned because of associations that connect the new with the known.

5) Most of the used words have multiple meanings.

6) Vocabulary instruction directly influences comprehension.

7) Teaching fewer words well is more effective than teaching many words in a cursory way.

8) Effective teachers display an attitude of excitement and interest in words and language.

9) The meaning of $60 \%$ of multisyllabic words can be inferred by analyzing word parts.

A study done by Laufer (1992) showed the important role of vocabulary size in reading comprehension. The study found that a reader whose vocabulary size is not large enough to support coverage of $95 \%$ of the words in a passage will not achieve appropriate reading comprehension.

In a suburban school district, Harmon (1999) investigated the strategies students used to guess word meanings while they read independently. The results showed that the major strategies used by students consisted of looking for clues from the local context. They also combined other strategies like word analysis and using dictionaries. Chen (1998) investigated Chinese EFL learners' vocabulary learning strategies. The results indicated that the students believed that using bilingual dictionaries was the most useful strategy to discover the meaning, and verbal repetition was the strategy used most to consolidate the meaning of a word.

Walters (2009) conducted a study in which he found that vocabulary notebooks can be an effective learning tool in EFL classrooms, but positive impacts on learner autonomy may not be seen in the absence of appropriate motivation for language learning.

McCollin, O'Shea, and McQuiston (2010) claim that secondary-level students from culturally and linguistically diverse (CLD) backgrounds who struggle with reading need strategies for aligning new information with their previous knowledge as well as for obtaining and retaining essential information from the text. Important components of all secondary literacy support must include instruction in word identification, vocabulary, and comprehension skills. 
Thu (2009) examined the language-learning strategies employed by successful learners of English as a foreign and second language. Two learners whose first language was Mandarin were interviewed, and asked to complete a questionnaire and a self-evaluation measure to indicate their perceived level of language proficiency as well as their learning goals for each individual language skill in the future. It was found that, in terms of motivation, one was learning English to excel and to use the language as well as native speakers; the other was learning English for her daily communication and academic study in the US. The data from the interviews and the questionnaires showed that these learners utilized a wide range of strategies to learn listening, reading, speaking, writing, pronunciation, grammar and vocabulary. It was also found that strategies for vocabulary learning outnumbered those for other language skills and areas investigated. Social strategies were found to be widely used by the learners to improve their English. Additionally, practice was reported to be the key to improving all four language skills as well as pronunciation, grammar, and vocabulary.

Pierce, Fontaine, and Melena (2009) reported that language skills are becoming an increasingly important feature of performance in mathematics classrooms. This new focus on language highlights the need to identify math vocabulary words and to apply research-based principles for vocabulary instruction in mathematics lessons. The article offers one way to analyze state high-stakes math tests to identify those words that children would benefit most from learning. An example of robust vocabulary instruction is provided.

Kindle (2009) notes that reading aloud is a common practice in primary classrooms and is viewed as an important vehicle for vocabulary development. Research indicates that interactive read-aloud styles and adult mediation of word learning are effective in enhancing word learning, but less is known about the actual practices of primary teachers. Read-alouds are complex instructional interactions in which teachers choose texts, identify words for instruction, and select the appropriate strategies to facilitate word learning.

Townsend and Collins (2009) conducted an experimental intervention study to determine whether evidence-based instructional strategies for learning general vocabulary words are effective with middle-school English learner (EL) students and particularly in their learning of academic vocabulary. Participants showed significantly more growth in their knowledge of academic vocabulary during the treatment situation than during the control situation. A secondary goal of this study was to examine the predictive utility of students' English language proficiency, and students' general vocabulary knowledge in English as a positive predictor of their academic vocabulary growth during the intervention.

Kaivanpanah and Alavi (2008) investigated how accurately EFL learners assess their understanding of unknown words, and whether language proficiency and gender influence their self-assessment. The sample consisted of 110 students. The results indicated that learners' assessments are not reliable. Moreover, it was found that proficiency in the L2 as well as gender can influence learners' self-assessment.

In spite of the many studies that have been done in the field of vocabulary teaching, there is still lack of agreement among researchers on the effectiveness of particular strategies of teaching. An investigation of the different strategies EFL students use in deriving the meaning of unfamiliar words may help in determining which are the most helpful; students should be trained in using these.

The researchers reviewed the related literature (Cook, 2001; Visnga, 2008; Chern, 1995; Harmon, 1999; Haynes \& Bloch, 1995; Morrison, 1996), interviewed ten English language teachers in the English Language Skills program at King Saud University, and interviewed a number of students in different classes, to find out which vocabulary learning strategies are most used by students. The strategies are:

a) I try to sound it out, and it sounds like the meaning I guessed;

b) The spelling of the word is similar to that of a word I know;

c) I know what the (stem, prefix, or suffix) of the word means (please write down its meaning) ......;

d) According to the meaning of the sentences nearby;

e) According to the meaning of the whole passage;

f) I find the word must be a verb, an adjective, an adverb, or a noun. Please circle one;

g) I use previous knowledge about the topic;

h) I know the meaning of the word;

i) Other ..........

This study will identify which vocabulary-learning strategies are used by students use in their reading and vocabulary classes and which of these result in correct guessing of the meaning of unfamiliar words. The 
identification of these successful strategies will indicate the areas in which students need more training. It is hoped that the study's findings will suggest some useful recommendations for both teachers and students, particularly regarding those strategies in which EFL teachers need to receive intensive training.

\section{Methodology}

\subsection{Population and Sample}

The population of the study consisted of the first-year EFL students at King Saud University. The cluster sampling method was used in choosing the sample, which consisted of six male and six female classroom sections (120 male and 120 female students) of the preparatory year deanship in the academic year 2011-2012. Based on the English language proficiency test result which the university students sit to at the beginning of the academic year. Male and female students were divided into three groups. The first group consisted of levels one and two, the second of levels three and four, and the third of levels five and six.

\subsection{Design and Procedures}

This study was a survey study with two dependent variables (the students' ability to guess the meaning of unfamiliar English language words and the strategies they used in guessing the meanings) and two independent variables (the students' gender and language proficiency level).

\subsection{Instrumentation}

The instruments were a pre-test and a post-test of vocabulary in three versions (a version for levels one and two (group 1), another for levels three and four (group 2), and a third for levels five and six (group 3)). Each version of the pre-test consisted of a list of 50 words. In order to establish the validity of the test, it was given to a panel of EFL professors and teachers. All their recommendations were taken into consideration. In the pre-test the students were asked to write the meaning of the words in their mother tongue (Arabic). The purpose of the pre-test was just to identify the words which students did not know so as to include them in the post-test.

Each version of the post-test in its first script consisted of two reading texts including the 20 words which the students had not known in the pre-test. The two reading passages were chosen from the second semester textbook for each of the levels. In the post-test, students had to read the passages and derive the meanings of the underlined words. Following every test item, there was a question asking students to choose from a list the strategies they had used to derive the meaning of the test item.

To establish the reliability of the post-test in its final form, before starting the study the test was applied twice on a sample of students not included in the main study sample; there was a period of three weeks between the tests. Pearson correlation coefficient was calculated and the results were 93.4 for group one, 92.3 for group two, and 94.1 for group three.

The strategies included on the post-test, as listed above, were compiled by the researchers based on the review of the related literature (Cook, 2001; Visnga, 2008; Chern, 1995; Harmon, 1999; Haynes \& Bloch, 1995; Morrison, 1996). The subjects could choose one or more strategies from the list for every test item.

\section{Data Collection}

After the researchers got permission from the university and the EFL teachers of the chosen classes, the pre- and post-tests were administered by the researchers during regular class time.

The researchers explained the purpose of the study to the subjects and assured them that no one apart from the researchers would have access to any of their results. Then the students were given the vocabulary pre-test. The subjects were given 20 minutes to write down in Arabic the meanings of the words they knew. The papers were then collected and corrected by the researchers.

After preparing the exam, its validity and reliability were established as explained before. Then the students were given the test, each version consisting of two passages and 20 underlined words. The researchers read the instructions in English and explained to them in Arabic when this was needed. Then the subjects were asked to try their best to guess the meanings of all the underlined English words. Every vocabulary test item was followed by a question inquiring which strategies had been used to derive the meaning of the word. All the strategies were explained to the students in Arabic when this was needed.

The students were given 45 minutes to read the two passages and to derive the meanings of the vocabulary test items. After that the papers were collected and given to a number of EFL instructors to mark. Each paper was corrected by three EFL instructors for consistency. Each correct answer was given one point. 


\section{Results}

Descriptive statistics, means and standard deviations, and ANOVA tests of variance were used to analyze the data to identify both the most used strategies and the most effective ones. ANOVA tests were also used to identify the differences (if any) in the use of the strategies due to the independent variables. The strategies were sorted according to the frequency of use. The results are presented in the following tables.

\subsection{Results Related to Question 1}

How proficient are first-year Saudi university EFL students in guess unfamiliar word meanings? Table 1 below presents results of the three male students' groups.

Table 1. Frequencies and percentages of the male students' correct and incorrect answers to each of the twenty vocabulary questions

\begin{tabular}{|c|c|c|c|c|c|c|c|c|c|c|c|c|}
\hline \multirow{3}{*}{$\begin{array}{l}\text { Q } \\
\text { No. }\end{array}$} & \multicolumn{4}{|c|}{ Group 1} & \multicolumn{4}{|c|}{ Group 2} & \multicolumn{4}{|c|}{ Group 3} \\
\hline & \multicolumn{2}{|c|}{ Correct } & \multicolumn{2}{|c|}{ Incorrect } & \multicolumn{2}{|c|}{ Correct } & \multicolumn{2}{|c|}{ Incorrect } & \multicolumn{2}{|c|}{ Correct } & \multicolumn{2}{|c|}{ Incorrect } \\
\hline & $\mathrm{N}$ & $\%$ & $\mathrm{~N}$ & $\%$ & $\mathrm{~N}$ & $\%$ & $\mathrm{~N}$ & $\%$ & $\mathrm{~N}$ & $\%$ & $\mathrm{~N}$ & $\%$ \\
\hline 1 & 16 & 40 & 24 & 60 & 26 & 65 & 14 & 35 & 23 & 57.5 & 17 & 42.5 \\
\hline 2 & 15 & 37.5 & 25 & 62.5 & 26 & 65 & 14 & 35 & 20 & 50 & 20 & 50 \\
\hline 3 & 15 & 37.5 & 25 & 62.5 & 24 & 60 & 16 & 40 & 23 & 57.5 & 17 & 42.5 \\
\hline 4 & 16 & 40 & 24 & 60 & 25 & 62.5 & 15 & 37.5 & 24 & 60 & 16 & 40 \\
\hline 5 & 17 & 42.5 & 23 & 57.5 & 21 & 52.5 & 19 & 47.5 & 23 & 57.5 & 17 & 42.5 \\
\hline 6 & 18 & 45 & 22 & 56 & 23 & 57.5 & 17 & 42.5 & 22 & 56 & 18 & 45 \\
\hline 7 & 19 & 47.5 & 21 & 52.5 & 21 & 52.5 & 19 & 47.5 & 23 & 57.5 & 17 & 42.5 \\
\hline 8 & 19 & 47.5 & 21 & 52.5 & 20 & 50 & 18 & 45 & 26 & 65 & 14 & 35 \\
\hline 9 & 21 & 53.5 & 19 & 47.5 & 20 & 50 & 20 & 50 & 25 & 62.5 & 15 & 37.5 \\
\hline 10 & 17 & 42.5 & 23 & 57.5 & 19 & 47.5 & 21 & 52.5 & 23 & 57.5 & 17 & 42.5 \\
\hline 11 & 17 & 42.5 & 23 & 57.5 & 20 & 50 & 20 & 50 & 22 & 56 & 18 & 45 \\
\hline 12 & 15 & 37.5 & 25 & 62.5 & 17 & 42.5 & 13 & 32.5 & 20 & 50 & 20 & 50 \\
\hline 13 & 17 & 42.5 & 23 & 57.5 & 20 & 50 & 18 & 45 & 24 & 60 & 16 & 40 \\
\hline 14 & 14 & 35 & 26 & 65 & 18 & 45 & 22 & 56 & 20 & 50 & 20 & 50 \\
\hline 15 & 16 & 40 & 24 & 60 & 21 & 52.5 & 19 & 47.5 & 21 & 52.5 & 19 & 47.5 \\
\hline 16 & 14 & 35 & 26 & 65 & 20 & 50 & 20 & 50 & 24 & 60 & 16 & 40 \\
\hline 17 & 18 & 45 & 22 & 56 & 19 & 47.5 & 21 & 52.5 & 20 & 50 & 20 & 50 \\
\hline 18 & 17 & 42.5 & 23 & 57.5 & 21 & 52.5 & 19 & 47.5 & 26 & 65 & 14 & 35 \\
\hline 19 & 17 & 42.5 & 23 & 57.5 & 22 & 56 & 18 & 45 & 22 & 56 & 18 & 45 \\
\hline \multirow[t]{2}{*}{20} & 15 & 37.5 & 25 & 62.5 & 25 & 62.5 & 15 & 37.5 & 22 & 56 & 18 & 45 \\
\hline & 333 & 42 & 467 & 58 & 428 & 54 & 372 & 46 & 452 & 56.5 & 347 & 43.5 \\
\hline
\end{tabular}

The results of Table1 show that the students' ability to guess the meaning of unfamiliar words is weak. The percentages of the correct answers of groups 1,2 and 3 are $42 \%, 54 \%$, and $56.5 \%$, respectively.

Table 2. Frequencies and percentages of the female students' correct and incorrect answers to each of the twenty vocabulary questions

\begin{tabular}{lllllllllllll}
\hline Q & \multicolumn{1}{l}{ Group 1 } & \multicolumn{1}{l}{ Group 2 } \\
No. & \multicolumn{1}{l}{ Correct } & \multicolumn{1}{l}{ Incorrect } & \multicolumn{2}{c}{ Correct } & \multicolumn{2}{c}{ Incorrect } & \multicolumn{2}{c}{ Correct } & \multicolumn{2}{c}{ Incorrect } \\
& $\mathrm{N}$ & $\%$ & $\mathrm{~N}$ & $\%$ & $\mathrm{~N}$ & $\%$ & $\mathrm{~N}$ & $\%$ & $\mathrm{~N}$ & $\%$ & $\mathrm{~N}$ & $\%$ \\
\hline 1 & 18 & 45 & 22 & 56 & 21 & 52.5 & 19 & 47.5 & 15 & 37.5 & 25 & 62.5 \\
2 & 15 & 37.5 & 25 & 62.5 & 20 & 50 & 20 & 50 & 21 & 52.5 & 19 & 47.5 \\
3 & 17 & 42.5 & 23 & 57.5 & 22 & 56 & 22 & 56 & 20 & 50 & 20 & 50 \\
\hline
\end{tabular}




\begin{tabular}{lllllllllllll}
\hline 4 & 14 & 35 & 26 & 65 & 18 & 45 & 18 & 45 & 23 & 57.5 & 17 & 42.5 \\
5 & 18 & 45 & 22 & 56 & 15 & 37.5 & 15 & 37.5 & 26 & 65 & 14 & 35 \\
6 & 10 & 25 & 30 & 75 & 12 & 30 & 12 & 30 & 27 & 67.5 & 13 & 32.5 \\
7 & 17 & 42.5 & 23 & 57.5 & 15 & 37.5 & 15 & 37.5 & 22 & 56 & 18 & 45 \\
8 & 16 & 40 & 24 & 60 & 17 & 42.5 & 17 & 42.5 & 18 & 45 & 22 & 56 \\
9 & 14 & 35 & 26 & 65 & 13 & 32.5 & 13 & 32.5 & 25 & 62.5 & 15 & 37.5 \\
10 & 14 & 35 & 26 & 65 & 13 & 32.5 & 13 & 32.5 & 25 & 62.5 & 15 & 37.5 \\
11 & 15 & 37.5 & 25 & 62.5 & 13 & 32.5 & 13 & 32.5 & 22 & 56 & 18 & 45 \\
12 & 13 & 32.5 & 27 & 67.5 & 10 & 25 & 10 & 25 & 21 & 52.5 & 19 & 47.5 \\
13 & 17 & 42.5 & 23 & 57.5 & 13 & 32.5 & 13 & 32.5 & 26 & 65 & 14 & 35 \\
14 & 13 & 32.5 & 27 & 67.5 & 13 & 32.5 & 13 & 32.5 & 24 & 60 & 16 & 40 \\
15 & 11 & 27.5 & 29 & 72.5 & 13 & 32.5 & 13 & 32.5 & 20 & 50 & 20 & 50 \\
16 & 13 & 32.5 & 27 & 67.5 & 17 & 42.5 & 17 & 42.5 & 23 & 57.5 & 17 & 42.5 \\
17 & 12 & 30 & 28 & 70 & 16 & 40 & 16 & 40 & 23 & 57.5 & 17 & 42.5 \\
18 & 12 & 30 & 28 & 70 & 17 & 42.5 & 17 & 42.5 & 25 & 62.5 & 15 & 37.5 \\
19 & 12 & 30 & 28 & 70 & 18 & 45 & 18 & 45 & 25 & 62.5 & 15 & 37.5 \\
20 & 15 & 37.5 & 25 & 62.5 & 16 & 40 & 16 & 40 & 23 & 57.5 & 17 & 42.5 \\
\hline & 286 & 36 & 514 & 64 & 312 & 39 & 488 & 61 & 454 & 57 & 346 & 43 \\
\hline
\end{tabular}

Table 2 shows that, as in the case of the male students, the female students' ability to guess the meaning of unfamiliar words is also weak. The percentages of the correct answers of groups 1,2 and 3 are $36 \%, 39 \%$ and $57 \%$, respectively. Table 3 below presents the guessing rate out of 20 .

Table 3. Frequencies and percentages of the students' scores and guessing rate

\begin{tabular}{llllllllll}
\hline & Score & \multicolumn{2}{c}{ Group 1 } & \multicolumn{2}{c}{ Group 2 } & \multicolumn{2}{c}{ Group 3 } & \multicolumn{2}{c}{ Total } \\
\cline { 3 - 10 } & & F & $\%$ & F & $\%$ & F & $\%$ & F & $\%$ \\
\hline Male & $1 \leq 5$ & 8 & 20.00 & 3 & 07.50 & 00 & 00.00 & 11 & 9.17 \\
& $>5 \leq 10$ & 27 & 67.50 & 14 & 35.00 & 16 & 42.50 & 57 & 47.5 \\
& $>10 \leq 15$ & 5 & 12.50 & 22 & 55.00 & 21 & 50.00 & 48 & 40.00 \\
& $>15 \leq 20$ & 00 & 00.00 & 1 & 02.50 & 3 & 07.50 & 4 & 3.33 \\
Female & $1 \leq 5$ & 12 & 30.00 & 18 & 45.00 & 00 & 00.00 & 30 & 25.00 \\
& $>5 \leq 10$ & 26 & 65.00 & 15 & 37.50 & 11 & 27.50 & 52 & 43.33 \\
& $>10 \leq 15$ & 00 & 00.00 & 6 & 15.00 & 28 & 70.00 & 34 & 28.33 \\
Total & $>15 \leq 20$ & 2 & 5.00 & 1 & 02.50 & 1 & 02.50 & 4 & 3.33 \\
& $1 \leq 5$ & 20 & 25.00 & 21 & 26.25 & 00 & 00.00 & 41 & 17.08 \\
& $>5 \leq 10$ & 53 & 66.25 & 29 & 36.25 & 27 & 33.75 & 109 & 45.17 \\
& $>10 \leq 15$ & 5 & 6.25 & 28 & 35.00 & 49 & 61.25 & 82 & 34.17 \\
& $>15 \leq 20$ & 2 & 2.50 & 2 & 2.50 & 4 & 5.00 & 8 & 3.33 \\
\hline
\end{tabular}

Table 3 shows that of the male students, 35, 17, and 16 from the first, second and third groups respectively scored less than 10 out of 20 in the post-test exam. It also shows that 5,22 , and 21 from the same groups respectively scored between 11 and 15 . Only one student from group 2 and group 3 scored higher than 15 out of 20.

The female students' results were not better than those of the male students. 38, 33, and 10 from the three groups respectively scored less than 10 out of 20 in the post-test exam. Only two from group 1, one from group 2, and one from group 3 scored higher than 15 out of 20. This indicates that students had problems in guessing the meaning of unfamiliar words which might be due to the strategies they use. 


\subsection{Results Related to Question 2}

What strategies do first-year EFL students use to derive unfamiliar word meanings?

Table 4. Frequencies and percentages of the strategies group one male students used to derive the meaning of unknown words (single and combined strategies)

\begin{tabular}{lllllll}
\hline Strategy & F & \multicolumn{2}{l}{ Correct } & \multicolumn{2}{l}{ Incorrect } \\
\cline { 3 - 6 } & & F & $\%$ & F & $\%$ & $\begin{array}{l}\text { in Terms } \\
\text { of Percentage of } \\
\text { Correct Answers }\end{array}$ \\
\hline Strategy A & 135 & 29 & 21.48 & 106 & 78.52 & 14 \\
Strategy B & 152 & 30 & 19.74 & 122 & 80.26 & 15 \\
Strategy C & 117 & 51 & 43.59 & 66 & 56.41 & 13 \\
Strategy D & 115 & 52 & 45.22 & 63 & 54.78 & 11 \\
Strategy E & 64 & 38 & 59.38 & 26 & 40.62 & 7 \\
Strategy F & 6 & 3 & 50.00 & 3 & 50.00 & 9 \\
Strategy G & 17 & 8 & 47.06 & 9 & 52.64 & 10 \\
Strategy H & 8 & 5 & 62.50 & 3 & 37.50 & 6 \\
Strategy I & 1 & 1 & 100 & 00 & 00 & 1 \\
Strategies (A, D \& E) & 27 & 12 & 44.49 & 15 & 55.51 & 12 \\
Strategies (A, B \& C) & 24 & 22 & 91.67 & 2 & 7.33 & 5 \\
Strategies (C, D \& E) & 15 & 14 & 93.33 & 1 & 6.67 & 4 \\
Strategies (A \& B) & 23 & 4 & 17.39 & 19 & 82.61 & 16 \\
Strategies (E \& D) & 1 & 00 & 00 & 1 & 100 & 17 \\
Strategies (C \& D) & 14 & 7 & 50 & 7 & 50 & 8 \\
Strategies (C, B \& D) & 6 & 6 & 100 & 00 & 00 & 1 \\
Strategies (A, B \& E) & 1 & 1 & 100 & 00 & 00 & 1 \\
Strategies (A, C \& D) & 3 & 00 & 00 & 3 & 100 & 17 \\
\hline & 728 & & & & & \\
\hline
\end{tabular}

Table 4 shows that although strategy B ("The spelling of the word was similar to that of a word I know") is used the most by the students (152 times), it ranked 15 th in terms of the percentage of correct answers resulting from its use (19.74\%). It is followed by strategy A (21.48\%); these come in the last two positions of instances of use of a single strategy.

The use of Strategy D ("According to the meaning of the sentences nearby") resulted in the highest number of correct answers but ranked 11th in terms of the percentage of correct answers. The combinations of strategies A, $\mathrm{B}$ and $\mathrm{C}$ and $\mathrm{C}, \mathrm{D}$ and $\mathrm{E}$ are used 24 and 15 times; 22 and 14 were correct answere.

Table 5. Frequencies and percentages of the strategies group two male students used to derive the meaning of unknown words (single and combined strategies)

\begin{tabular}{|c|c|c|c|c|c|c|}
\hline \multirow[t]{2}{*}{ Strategy } & \multirow[t]{2}{*}{$\bar{F}$} & \multicolumn{2}{|c|}{ Correct } & \multicolumn{2}{|c|}{ Incorrect } & \multirow{2}{*}{$\begin{array}{l}\text { Rank in Terms } \\
\text { of Percentage of } \\
\text { Correct Answers }\end{array}$} \\
\hline & & $\mathrm{F}$ & $\%$ & F & $\%$ & \\
\hline Strategy A & 100 & 50 & 50.00 & 60 & 50.00 & 8 \\
\hline Strategy B & 124 & 24 & 19.35 & 100 & 80.65 & 12 \\
\hline Strategy C & 56 & 32 & 57.14 & 24 & 42.86 & 7 \\
\hline Strategy D & 24 & 16 & 66.67 & 8 & 33.33 & 5 \\
\hline Strategy E & 74 & 68 & 19.89 & 6 & 80.11 & 11 \\
\hline Strategy F & 140 & 84 & 60.00 & 56 & 40.00 & 6 \\
\hline Strategy G & 80 & 20 & 25.00 & 60 & 75.00 & 10 \\
\hline
\end{tabular}




\begin{tabular}{lllllll}
\hline Strategy H & 00 & 00 & 00.00 & 00 & 00.00 & 13 \\
Strategy I & 00 & 00 & 00.00 & 00 & 00.00 & 13 \\
Strategies (D \& E) & 84 & 76 & 90.48 & 8 & 9.52 & 1 \\
Strategies (D \& F) & 44 & 36 & 81.82 & 8 & 18.18 & 2 \\
Strategies (D \& A) & 8 & 4 & 50.00 & 4 & 50.00 & 8 \\
Strategies (A \& B) & 16 & 12 & 75.00 & 4 & 25.00 & 4 \\
Strategies (D \& C) & 20 & 16 & 80.00 & 4 & 20 & 3 \\
\hline & 770 & & & & \\
\hline
\end{tabular}

Table 5 shows that strategy "F" ("I find the word must be a verb, an adjective, an adverb, or a noun") is used the most by the students (140 times); 80 are correct $(60 \%)$ and strategy $\mathrm{F}$ ranks $6^{\text {th }}$ in terms of the percentage of correct answers. In frequency of use, the use of strategy" F" is followed by the use of strategy "B" (124 times), which resulted in $19.35 \%$ correct answers only.

The combinations of the use of strategies "D and E" and strategies "D and F" are used 84 and 44 times respectively resulting in $90.48 \%$ and $81.82 \%$ correct answers and ranked first and second.

Table 6. Frequencies and percentages of the strategies group three male students used to derive the meaning of unknown words (single and combined strategies)

\begin{tabular}{|c|c|c|c|c|c|c|}
\hline \multirow[t]{2}{*}{ Strategy } & \multirow[t]{2}{*}{$\mathrm{F}$} & \multicolumn{2}{|c|}{ Correct } & \multicolumn{2}{|c|}{ Incorrect } & \multirow{2}{*}{$\begin{array}{l}\text { Rank in Terms } \\
\text { of Percentage of } \\
\text { Correct Answers }\end{array}$} \\
\hline & & $\mathrm{F}$ & $\%$ & $\mathrm{~F}$ & $\%$ & \\
\hline Strategy A & 147 & 33 & 22.45 & 114 & 77.55 & 17 \\
\hline Strategy B & 153 & 30 & 19.61 & 123 & 80.39 & 19 \\
\hline Strategy C & 69 & 62 & 89.86 & 7 & 10.14 & 9 \\
\hline Strategy D & 59 & 52 & 88.14 & 9 & 11.86 & 11 \\
\hline Strategy E & 68 & 61 & 89.71 & 7 & 10.29 & 10 \\
\hline Strategy F & 22 & 15 & 68.18 & 7 & 31.82 & 13 \\
\hline Strategy G & 12 & 4 & 33.33 & 8 & 66.67 & 16 \\
\hline Strategy H & 00 & 00 & 00.00 & 00 & 00.00 & 20 \\
\hline Strategy I & 00 & 00 & 00.00 & 00 & 00.00 & 20 \\
\hline Strategies (A,B \& D) & 8 & 6 & 75.00 & 2 & 25.00 & 12 \\
\hline Strategies $(C \& G)$ & 2 & 2 & 100.00 & 00 & 00.00 & 1 \\
\hline Strategies (B \& G) & 1 & 1 & 100.00 & 00 & 00.00 & 1 \\
\hline Strategies (E \& F) & 15 & 15 & 100.00 & 00 & 00.00 & 1 \\
\hline Strategies (A, B \& E) & 5 & 1 & 20.00 & 4 & 80.00 & 18 \\
\hline Strategies (A, B \& C) & 36 & 23 & 63.89 & 13 & 36.11 & 14 \\
\hline Strategies (C \& F) & 3 & 3 & 100.00 & 00 & 00.00 & 1 \\
\hline Strategies (A \& B) & 51 & 29 & 56.86 & 22 & 43.14 & 15 \\
\hline Strategies (C, D \& F) & 48 & 47 & 97.92 & 1 & 2.80 & 8 \\
\hline Strategies (C, D \& E) & 53 & 52 & 98.11 & 1 & 1.89 & 7 \\
\hline Strategies (E \& B) & 3 & 3 & 100.00 & 00 & 00.00 & 1 \\
\hline \multirow[t]{2}{*}{ Strategies (C \& D) } & 3 & 3 & 100.00 & 00 & 00.00 & 1 \\
\hline & 758 & & & & & \\
\hline
\end{tabular}

Table 6 shows that strategies B and A are used the most, 153 and 147 times respectively of which only $22.45 \%$ and $19.61 \%$ respectively produce correct answers. They rank $17^{\text {th }}$ and $19^{\text {th }}$ in terms of these percentages.

The combination of strategies " $\mathrm{E} \& \mathrm{~F}$ " is used 15 times; all answers are correct. The use of the combinations of the strategies "C \& G", "B \& G", " C \& F", "E \& B", and "C \& D" also results in perfect answers but they are 
not used so much: only $2,1,3,3$, and 3 times respectively. The combination of the strategies "C, D \& E" is used 53 times: 52 answers are correct.

Table 7. Frequencies and percentages of the strategies group one female students used to derive the meaning of unknown words (single and combined strategies)

\begin{tabular}{lllllll}
\hline Strategy & F & \multicolumn{2}{l}{ Correct } & \multicolumn{2}{l}{ Incorrect } & $\begin{array}{l}\text { Rank in Terms } \\
\text { of Percentage of } \\
\text { Correct Answers }\end{array}$ \\
\cline { 3 - 6 } & & F & $\%$ & F & $\%$ & 12 \\
\hline Strategy A & 116 & 10 & 8.62 & 106 & 91.38 & 12 \\
Strategy B & 130 & 12 & 9.23 & 118 & 90.77 & 11 \\
Strategy C & 128 & 31 & 24.22 & 97 & 75.78 & 10 \\
Strategy D & 116 & 34 & 29.31 & 82 & 71.69 & 9 \\
Strategy E & 133 & 69 & 51.88 & 64 & 48.12 & 7 \\
Strategy F & 30 & 2 & 6.67 & 28 & 93.33 & 13 \\
Strategy G & 56 & 38 & 67.86 & 18 & 32.14 & 6 \\
Strategy H & 5 & 4 & 80.00 & 1 & 20.00 & 4 \\
Strategy I & 00 & 00 & 00.00 & 00 & 00.00 & 14 \\
Strategies (A, B \& C) & 29 & 28 & 96.55 & 1 & 3.45 & 3 \\
Strategies (A \& B) & 6 & 00 & 00.00 & 6 & 100.00 & 14 \\
Strategies (A, D \& C) & 18 & 9 & 50.00 & 9 & 50.00 & 8 \\
Strategies (A, B \& D) & 4 & 3 & 75.00 & 1 & 25.00 & 5 \\
Strategies (C, D \& E) & 12 & 12 & 100.00 & 00 & 00.00 & 1 \\
Strategies (C, D \& F) & 6 & 6 & 100.00 & 00 & 00.00 & 1 \\
\hline & 789 & & & & & \\
\hline
\end{tabular}

Table 7 shows that strategies E, B, C, A, and D are used 133, 130, 128, 116, and 116 times respectively and rank $7^{\text {th }}, 11^{\text {th }}, 10^{\text {th }}, 12^{\text {th }}$, and $9^{\text {th }}$ respectively in terms of the percentage of correct answers.

The use of the combinations of strategies CDF and CDE is perfect, resulting in $100 \%$ correct answers, but they are used only 12 and 6 times respectively. The combination ABC is used 29 times of which 28 produce correct answers.

Table 8. Frequencies and percentages of the strategies group two female students used to derive the meaning of unknown words (single and combined strategies)

\begin{tabular}{lllllll}
\hline Strategy & F & \multicolumn{2}{l}{ Correct } & \multicolumn{2}{l}{ Incorrect } & $\begin{array}{l}\text { Rank in Terms } \\
\text { of Percentage of } \\
\text { Correct Answers }\end{array}$ \\
\cline { 3 - 6 } & & $F$ & $\%$ & F & $\%$ & \\
\hline Strategy A & 153 & 14 & 9.15 & 139 & 90.85 & 16 \\
Strategy B & 152 & 33 & 21.71 & 124 & 7829 & 15 \\
Strategy C & 55 & 13 & 23.64 & 42 & 76.36 & 14 \\
Strategy D & 92 & 35 & 38.04 & 57 & 61.96 & 12 \\
Strategy E & 54 & 29 & 53.70 & 25 & 46.30 & 9 \\
Strategy F & 11 & 8 & 72.72 & 3 & 27.18 & 6 \\
Strategy G & 20 & 5 & 25.00 & 15 & 75.00 & 13 \\
Strategy H & 00 & 00 & 00.00 & 00 & 00.00 & 17 \\
Strategy I & 00 & 00 & 00.00 & 00 & 00.00 & 17 \\
Strategies (A, B \& G) & 1 & 1 & 100.00 & 00 & 00.00 & 1 \\
Strategies (H, A \& I) & 1 & 1 & 100.00 & 00 & 00.00 & 1 \\
Strategies (A, D \& E) & 2 & 2 & 100.00 & 00 & 00.00 & 1 \\
\hline
\end{tabular}




\begin{tabular}{lllllll}
\hline Strategies (B, F \& I) & 3 & 00 & 00.00 & 3 & 100.00 & 17 \\
Strategies (F, B \& E) & 1 & 00 & 00.00 & 1 & 100.00 & 17 \\
Strategies (D, E \& G) & 3 & 00 & 00.00 & 3 & 100.00 & 17 \\
Strategies (A \& G) & 2 & 2 & 100.00 & 00 & 00.00 & 1 \\
Strategies (A, B \& I) & 25 & 15 & 60.00 & 10 & 40.00 & 8 \\
Strategies (D \& C) & 4 & 3 & 75.00 & 1 & 25.00 & 5 \\
Strategies (D \& E) & 42 & 22 & 52.38 & 20 & 47.62 & 11 \\
Strategies (A, B \& C) & 17 & 9 & 52.94 & 8 & 47.04 & 10 \\
Strategies (A, B \& E) & 8 & 5 & 62.50 & 3 & 67.50 & 7 \\
\hline & 702 & & & &
\end{tabular}

Table 8 shows that strategies A, B and C are used the most: 153,152 and 92 times respectively but rank $16^{\text {th }}, 15^{\text {th }}$ and $12^{\text {th }}$ respectively in terms of the percentage of correct answers. Although the combinations of strategies ABG, HAI, ADE and AG are used only once or twice each, they result in $100 \%$ correct answers.

Table 9. Frequencies and percentages of the strategies group three female students used to derive the meaning of unknown words (single and combined strategies)

\begin{tabular}{|c|c|c|c|c|c|c|}
\hline \multirow[t]{2}{*}{ Strategy } & \multirow[t]{2}{*}{$\mathrm{F}$} & \multicolumn{2}{|c|}{ Correct } & \multicolumn{2}{|c|}{ Incorrect } & \multirow{2}{*}{$\begin{array}{l}\text { Rank in Terms } \\
\text { of Percentage of } \\
\text { Correct Answers }\end{array}$} \\
\hline & & F & $\%$ & $\mathrm{~F}$ & $\%$ & \\
\hline Strategy A & 121 & 30 & 24.79 & 101 & 75.21 & 16 \\
\hline Strategy B & 129 & 14 & 10.85 & 115 & 89.15 & 17 \\
\hline Strategy C & 84 & 61 & 72.62 & 23 & 27.38 & 10 \\
\hline Strategy D & 84 & 63 & 70.00 & 21 & 30.00 & 12 \\
\hline Strategy E & 79 & 74 & 93.67 & 5 & 6.33 & 9 \\
\hline Strategy F & 28 & 18 & 64.29 & 10 & 35.71 & 13 \\
\hline Strategy G & 30 & 12 & 40.00 & 18 & 60.00 & 15 \\
\hline Strategy H & 3 & 00 & 00.00 & 3 & 100.00 & 18 \\
\hline Strategy I & 00 & 00 & 00.00 & 00 & 00.00 & 18 \\
\hline Strategies (A, B \& C) & 21 & 15 & 71.43 & 6 & 28.57 & 11 \\
\hline Strategies (A \& B) & 55 & 25 & 54.45 & 30 & 45.55 & 14 \\
\hline Strategies (C, D \& E) & 67 & 66 & 98.51 & 1 & 1.49 & 8 \\
\hline Strategies (C, D \& F) & 54 & 54 & 100.00 & 00 & 00.00 & 1 \\
\hline Strategies (A, D \& E) & 10 & 10 & 100.00 & 00 & 00.00 & 1 \\
\hline Strategies (C \& F) & 6 & 6 & 100.00 & 00 & 00.00 & 1 \\
\hline Strategies (C, F \& G) & 3 & 3 & 100.00 & 00 & 00.00 & 1 \\
\hline Strategies (E \& F) & 6 & 6 & 100.00 & 00 & 00.00 & 1 \\
\hline Strategies (A \& C) & 1 & 00 & 00.00 & 1 & 100.00 & 18 \\
\hline Strategies (A \& D) & 3 & 3 & 100.00 & 00 & 00.00 & 1 \\
\hline Strategies (A, B \& D) & 6 & 6 & 100.00 & 00 & 00.00 & 1 \\
\hline
\end{tabular}

Table 9 shows that strategies B, A, D and C are used the most: 129, 121, 84, and 84 times respectively but rank $17^{\text {th }}, 16^{\text {th }}, 12^{\text {th }}$, and $10^{\text {th }}$ respectively in terms of the percentage of correct answers.

The combination of strategies CDE is used 67 times resulting in 66 correct answers. CDF is used 54 times with $100 \%$ success. Although combinations $\mathrm{ABD}, \mathrm{AD}, \mathrm{ADE}, \mathrm{CF}, \mathrm{CFG}, \mathrm{EF}$ and $\mathrm{AC}$ are not used as much, they also result in $100 \%$ correct answers. 


\subsection{Results Related to Question 3}

What strategies do first-year Saudi university EFL students use which result in the correct derivation of unfamiliar word meanings? Tables 10 and 11 below present the strategies which resulted in correct derivations.

Table 10. Rank order of the strategies resulting in correct derivations: male students of all three groups (single and combined strategies)

\begin{tabular}{|c|c|c|c|c|c|c|c|}
\hline \multirow[t]{2}{*}{ Strategy } & \multirow[t]{2}{*}{$\mathrm{F}$} & \multicolumn{2}{|c|}{ Correct } & \multicolumn{2}{|c|}{ Incorrect } & \multirow{2}{*}{$\begin{array}{l}\text { Rank in Terms } \\
\text { of Frequency of } \\
\text { Correct Answers }\end{array}$} & \multirow{2}{*}{$\begin{array}{l}\text { Rank in Terms } \\
\text { of Percentage of } \\
\text { Correct Answers }\end{array}$} \\
\hline & & F & $\%$ & $\mathrm{~F}$ & $\%$ & & \\
\hline Strategy A & 392 & 112 & 28.57 & 280 & 71.43 & 2 & 22 \\
\hline Strategy B & 429 & 84 & 19.58 & 345 & 80.42 & 1 & 23 \\
\hline Strategy C & 242 & 97 & 40.08 & 97 & 59.92 & 3 & 19 \\
\hline Strategy D & 198 & 120 & 60.61 & 78 & 39.39 & 5 & 15 \\
\hline Strategy E & 235 & 185 & 78.72 & 50 & 21.28 & 4 & 12 \\
\hline Strategy F & 186 & 107 & 57.53 & 79 & 42.47 & 6 & 16 \\
\hline Strategy G & 130 & 42 & 30.31 & 93 & 69.69 & 7 & 21 \\
\hline Strategy H & 8 & 5 & 62.50 & 3 & 38.50 & 17 & 14 \\
\hline Strategy I & 1 & 1 & 100.00 & 00 & 00.00 & & 1 \\
\hline Strategies (A \& B) & 90 & 45 & 50.00 & 45 & 50.00 & 8 & 17 \\
\hline Strategies (E \& D) & 85 & 76 & 89.41 & 9 & 10.59 & 9 & 9 \\
\hline Strategies (A, B \& D) & 10 & 8 & 80.00 & 2 & 20.00 & 16 & 11 \\
\hline Strategies (A, B \& E) & 6 & 2 & 33.33 & 4 & 66.67 & 18 & 20 \\
\hline Strategies (A, D \& C) & 3 & 00 & 00.00 & 3 & 100.00 & 19 & 24 \\
\hline Strategies (A, B \& C) & 60 & 45 & 75.00 & 15 & 25.00 & 10 & 13 \\
\hline Strategies (A, D \& E) & 27 & 12 & 44.44 & 15 & 55.56 & 13 & 18 \\
\hline Strategies (C \& G) & 2 & 2 & 100.00 & 00 & 00.00 & 22 & 1 \\
\hline Strategies (B \& G) & 1 & 1 & 100.00 & 00 & 00.00 & 23 & 1 \\
\hline Strategies (E \& F) & 15 & 15 & 100.00 & 00 & 00.00 & 15 & 1 \\
\hline Strategies (C \& F) & 3 & 3 & 100.00 & 00 & 00.00 & 19 & 1 \\
\hline Strategies (C, D \& F) & 48 & 47 & 97.92 & 1 & 2.08 & 12 & 8 \\
\hline Strategies (C, D \& E) & 53 & 52 & 98.11 & 1 & 1.89 & 11 & 7 \\
\hline Strategies (E \& B) & 3 & 3 & 100.00 & 00 & 00.00 & 19 & 1 \\
\hline Strategies (C \& D) & 23 & 19 & 82.61 & 4 & 17.39 & 14 & 10 \\
\hline
\end{tabular}

Table 10 shows that strategies B and A are used the most by the male students regardless of their group. They are used 429 and 392 times respectively but occupy the last two positions (positions $23^{\text {rd }}$ and $22^{\text {nd }}$ ) in terms of the percentages of correct answers. Although the use of the combinations of strategies EB, CF, EF, BG, and CG rank equal first in terms of the percentages of correct answers to the number of times used, they are not used very much $(3,3,1,1$, and 1 , respectively).

Table 11. Rank order of the strategies resulting in correct derivations: female students of all three groups (single and combined strategies)

\begin{tabular}{llllllll}
\hline Strategy & F & \multicolumn{2}{l}{ Correct } & \multicolumn{2}{l}{ Incorrect } & $\begin{array}{l}\text { Rank in Terms } \\
\text { of Frequency of } \\
\text { Correct Answers }\end{array}$ & $\begin{array}{l}\text { Rank in Terms } \\
\text { Correct Answers }\end{array}$ \\
\cline { 3 - 9 } & & F & $\%$ & F & $\%$ & & \\
\hline Strategy A & 408 & 62 & 15.20 & 346 & 84.80 & 2 & 25 \\
Strategy B & 409 & 99 & 24.21 & 310 & 75.79 & 1 & 24 \\
\hline
\end{tabular}




\begin{tabular}{llllllll}
\hline Strategy C & 267 & 105 & 39.33 & 162 & 60.67 & 4 & 22 \\
Strategy D & 292 & 132 & 45.21 & 160 & 54.79 & 3 & 19 \\
Strategy E & 266 & 172 & 64.66 & 94 & 35.34 & 5 & 13 \\
Strategy F & 121 & 43 & 35.54 & 78 & 64.46 & 6 & 23 \\
Strategy G & 106 & 55 & 51.89 & 51 & 48.11 & 7 & 18 \\
Strategy H & 8 & 4 & 50.00 & 4 & 50.00 & 18 & 17 \\
Strategy I & 00 & 00 & 00.00 & 00 & 00.00 & 27 & 27 \\
Strategies (A \& B) & 63 & 27 & 42.86 & 36 & 57.14 & 9 & 20 \\
Strategies (A, B \& C) & 52 & 45 & 86.54 & 7 & 13.46 & 11 & 11 \\
Strategies (A, D \& C) & 18 & 9 & 50.00 & 9 & 50.00 & 14 & 15 \\
Strategies (A, B \& D) & 10 & 9 & 90.00 & 1 & 10.00 & 17 & 10 \\
Strategies (C, D \& E) & 79 & 78 & 98.73 & 1 & 1.27 & 8 & 9 \\
Strategies (C, D \& F) & 60 & 60 & 100.00 & 00 & 00.00 & 10 & 1 \\
Strategies (C \& F) & 6 & 6 & 100.00 & 00 & 00.00 & 19 & 1 \\
Strategies (A, D \& E) & 11 & 11 & 100.00 & 00 & 00.00 & 15 & 1 \\
Strategies (C, F \& G) & 3 & 3 & 100.00 & 00 & 00.00 & 21 & 1 \\
Strategies (E \& F) & 6 & 6 & 100.00 & 00 & 00.00 & 19 & 12 \\
Strategies (A \& C) & 11 & 8 & 72.73 & 3 & 27.27 & 15 & 1 \\
Strategies (A, B \& G) & 1 & 1 & 100.00 & 00 & 00.00 & 22 & 1 \\
Strategies (A, H \& I) & 1 & 1 & 100.00 & 00 & 00.00 & 22 & 14 \\
Strategies (A \& H) & 13 & 00 & 00.00 & 13 & 100.00 & 1 & \\
Strategies (A, B \& I) & 25 & 15 & 60.00 & 10 & 40.00 & 13 & \\
Strategies (D \& E) & 42 & 22 & 52.38 & 20 & 47.62 & 12 & \\
\hline & 2278 & & & & & & \\
\hline
\end{tabular}

As in the case of the male students, strategies A, B, D, C, E and F are used the most $(408,409,292,267,266$, and 121 times respectively) and rank $25^{\text {th }}, 24^{\text {th, }} 19^{\text {th }} 22^{\text {nd, }} 13^{\text {th, }}$ and $23^{\text {rd }}$. The combination CDF is used 60 times, and all answers are correct. The use of the combinations ABG, AHI, ABG, EF, CFG, ADE, CF, and CDF results in $100 \%$ correct answers.

\subsection{Results Related to Question 4}

Does first-year Saudi university EFL students' ability to derive the meaning of unfamiliar words vary with respect to their gender and their language proficiency?

Table 12. Means and standard deviations of the different variables

\begin{tabular}{lllll}
\hline Variables & & $\mathrm{N}$ & Mean & Standard Deviation \\
\hline Whole & & 243 & 9.19 & 3.61 \\
\hline Gender & Male & 120 & 9.91 & 3.13 \\
& Female & 122 & 8.55 & 3.85 \\
\hline Levels & 1 & 41 & 7.29 & 2.22 \\
& 2 & 41 & 7.24 & 3.67 \\
& 3 & 40 & 8.98 & 4.15 \\
& 4 & 41 & 9.00 & 3.58 \\
& 5 & 39 & 11.49 & 2.11 \\
& 6 & 40 & 11.50 & 2.59 \\
\hline Group & 1 & 82 & 7.27 & 3.01 \\
& 2 & 81 & 8.99 & 3.85 \\
& 3 & 79 & 11.49 & 2.35 \\
\hline
\end{tabular}


Table 12 shows that there are clear differences due to the students' gender and their language proficiency group.

Table 13 below presents the results of ANOVA test to investigate whether these clear differences are significant.

Table 13. Results of ANOVA test

\begin{tabular}{llllll}
\hline Source & DF & Type III SS & Mean Square & F-Value & Pr \\
\hline gender & 1 & 112.24 & 112.24 & 12.81 & 0.0004 \\
Group & 2 & 723.19 & 361.59 & 41.26 & 0.0001 \\
Gender*Group & 2 & 163.76 & 82.88 & 9.34 & 0.0001 \\
Error & 236 & 2068.53 & 8.76 & & \\
Total & 241 & 3071.95 & & & \\
\hline
\end{tabular}

The results show that there is significant interaction between the students' gender and their language proficiency group. The results also show that there are two statistically significant differences. The first is between male and female students in favor of the male students $(\mathrm{F}=12.81, \mathrm{P}=0.0004)$ : The male students' guessing rate score is higher than the guessing rate score of the female students, their mean scores were 9.91 and 8.55 respectively. The second is among the language proficiency groups.

Table 14. Comparisons between language proficiency groups

\begin{tabular}{lllll}
\hline Groups & \multicolumn{3}{c}{$\begin{array}{l}\text { Difference } \\
\text { Between Means }\end{array}$} & $\begin{array}{l}\text { Simultaneous } \\
\text { Confidence Limits }\end{array}$ \\
\hline Table 1 & 2 & -1.7194 & -2.8133 & $-0.6254^{* *}$ \\
Table 1 & 3 & -4.2254 & -5.3262 & $-3.1245^{* *}$ \\
2 & 3 & -2.5060 & -3.6102 & $-1.4018^{* *}$ \\
\hline
\end{tabular}

** Significant $\alpha \leq 0.05$

The results show that the guessing rate scores of groups 2 and 3 are significantly higher than that of group 1; and the guessing rate score of group 3 is significantly higher than that of group 2 .

\subsection{Interaction between the Students' Gender and Their Proficiency Groups}

Table 15 below and Figure 1 present the means and standard deviations of the interaction between the students' gender and the language proficiency groups to which they belong.

Table 15. Interaction between gender and groups

\begin{tabular}{lllll}
\hline Levels of Gender & Levels of Group & $\mathrm{N}$ & Mean & Standard Deviation \\
\hline Male & 1 & 41 & 7.78 & 2.52 \\
Male & 2 & 40 & 10.78 & 2.97 \\
Male & 3 & 39 & 11.26 & 2.71 \\
Female & 1 & 41 & 6.76 & 3.38 \\
Female & 2 & 41 & 7.24 & 3.83 \\
Female & 3 & 40 & 11.73 & 1.94 \\
\hline
\end{tabular}




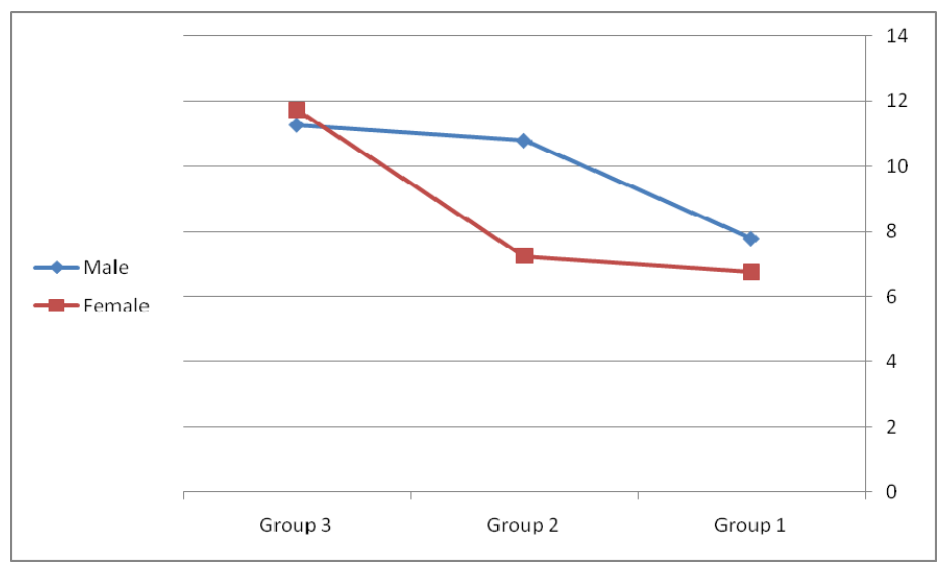

Figure 1. Interaction between gender and language proficiency groups

This figure shows that the guessing rate scores of male student groups 1 and 2 are higher than the female students' scores for the same groups. On the other hand, it shows that the score of group 3 of the female students is higher than the score of group 3 of the male students.

\section{Discussion of Results}

The results of the study show that these first-year Saudi university EFL students were weak in guessing the meaning of unfamiliar words. Most of the students tended to guess "According to the meaning of the sentence nearby" (Strategy D), and because "The spelling of the word is similar to a word I know" (Strategy B). The results show that $68(56.67 \%)$ of the male students and $82(68.33 \%)$ of the female students scored less than 10 out of 20 in the unknown word meaning guessing test. This could be attributed to the ineffective guessing strategies students used. The methods of teaching new words are still traditional in schools in the Arab World (Baniabdelrahman, 2004). EFL teachers concentrate on explaining the meaning of new words rather than training students to guess their meanings. Most of the time EFL teachers ask their students to look up the meaning of new words in dictionaries; students are rarely asked to guess the meaning from the context. Furthermore, EFL teachers do not train their students to use effective strategies for guessing the meaning of new words.

The low frequency of applying strategies that resulted in correct guessing of the meaning of unfamiliar words could be attributed to students' lack of related knowledge. Saudi first-year university students have difficulty in memorizing the prefix and suffix of words, for they process this kind of information as rules. With the limited vocabulary that students have, they may have very few chances to apply these rules in practice. Therefore retaining these rules becomes a burden to students.

The high number of students using strategies $\mathrm{A}, \mathrm{B}$ and $\mathrm{D}$ shows that many tended to rely on guessing strategies that they thought would be helpful but that turned out to be ineffective. The results indicate that the more strategy B was applied, the less likely it was that students would derive the correct meaning of the unfamiliar words. It seems that there is a weak correlation between the frequent use of strategies A, B and D and the correct derivation of the meaning of unfamiliar words. (This suggests that there is a need to train EFL students in the use of different guessing strategies and to focus on the most effective ones.) This result is in harmony with Haynes and Bloch's (1995) findings. Haynes and Bloch labeled this kind of mistake as ID, which means that students thought they knew a target word, but did not. The result also agrees with Coady's (1979) psycholinguistic model of ESL/EFL students' word meaning derivation strategies. According to Coady's model, high-school students are beginning ESL/EFL learners who should use more grapheme-phoneme, grapheme-morphophoneme, or syllable-morpheme correspondence clues instead of contextual meanings to comprehend reading materials.

Saudi first-year university EFL students devote large amounts of time to learning grammar. Teachers always stress the rules of how to put words together to make a grammatical sentence, and although some students find it easy to point out which part of speech the target word belongs to, this was not put into practice and was not reflected in the students' use of strategy F ("I find the word must be a verb, an adjective, an adverb, a noun ..."), which indicates that theoretical teaching is not effective in enabling students to put information into practice.

Although the results show that the use of a combination of two or more strategies usually results in a better correct guessing rate, few students tended to use this technique. This indicates that students are not trained well 
or do not know how to use such strategies. The results also show that most students tended to use look for clue words in the same sentence. Furthermore, weak students tended to use only one knowledge strategy; this finding supports the findings of Morrison (1996) and Haynes and Bloch (1995).

Regarding gender, although identical educational systems are used in the male and female schools and the male and female teachers are of the same backgrounds and always have the same qualifications, the results show that gender had a significant effect on the students' ability to guess the meaning of unfamiliar words in favor of the male students. This might be because male students in Saudi Arabia have more chance to travel abroad and have more contact with native speakers of English than female students do, but further research is needed here.

With regard to the level of language proficiency, the study revealed significant differences in favor of the higher groups. Group two students were better able to use the most suitable strategies than those in group one. The same result was found between groups three and two in favor of group three. This indicates that the higher the students' language proficiency, the more effective their use of vocabulary learning strategies. This suggests that teachers should pay more attention to training lower language proficiency students in how, when, and which strategies to use.

\section{Conclusion}

The study shows that although some strategies are rarely used, their use results in correct guessing of the meaning of unfamiliar words. This suggests that students are either not familiar with these strategies or they do not know how and when to use them. The results also indicate that the extensive use of some strategies does not result in accurate guessing of the meaning of unfamiliar words, suggesting that students in general are not always skillful in using the vocabulary learning strategies they most favor. Students either use some strategies randomly which leads to incorrect use, or they only use those strategies they are familiar with. Additionally, students sometimes know the linguistic category the unknown word belongs to, but this does not help them identify the meaning.

This indicates that teachers tend to provide merely theoretical training in vocabulary learning strategies; they may also be unaware of their students' needs. The results support the importance of practical training in when and how to use the various strategies: students need to be given regular practice in order to learn how to use them most effectively. Moreover, both EFL teachers and students need to understand the importance of using the most suitable strategies and should be extensively trained in how to use them. EFL teachers should be aware of the different vocabulary learning strategies their students actually use and they should also be encouraged to carry out action research studies to identify their students' weaknesses in order to help improve their abilities.

It can be concluded that the more strategies the students use together, the better results they have in correct guessing og the meaning of the new words. It is recommended to train students on how to combine three or four strategies to gather every time they face a word which they do not know.

\section{Implications}

1) Students should be trained in when and how to use the different vocabulary learning strategies.

2) Teachers should be aware of their students' weaknesses so that they can help in improving their abilities in vocabulary learning.

3) Since around $80 \%$ of the EFL teachers in the English Language Skills Program are native speakers, there is a need to familiarize them with the backgrounds of the students and the strategies which have been used in teaching them. These teachers should be aware that EFL students will tend to use different strategies in determining the meaning of new words from those that native-speaker students use.

4) EFL students' needs may differ from those of native speakers in dealing with the problems posed by unfamiliar words.

\section{Recommendations}

On the basis of these results, the researchers recommend that EFL teachers train their students in the use of a variety of strategies for guessing the meaning of unfamiliar words. Moreover, it is recommended that experimental studies be conducted on these strategies to determine which are the most effective.

\section{Acknowledgments}

This study is sponsored by the Research Center of the College of Education at King Saud University, Saudi Arabia. 


\section{References}

Aihara, K., Au, K., Carroll, J., Nakanishi, P., Scheu, J., \& Wong-Kam, J. A. (2000). The professional library. The Reading Teacher, 53(6), 495-498.

Allington, R. (2006). What Really Matters for Struggling Readers: Designing Research-Based Programs (2nd ed.). Boston: Allyn and Bacon.

Baniabdelrahman, A. (2004). The Effectiveness of the Use of Word Boxes Instruction on the Spelling Performance of EFL Fifth Grade Students. Abhath Al-Yarmouk: Humanities and Social Sciences Series, 20(4B).

Beck, I. L., Mckeown, M. G., \& Kucan, L. (2002). Bring Words to Life: Robust Vocabulary Instruction. New York: Guilford Press.

Bernhardt, E. B., \& Kamil, M. (1995). Interpreting relationships between L1 and L2 reading: Consolidating the linguistic threshold and the linguistic interdependence hypotheses. Applied Linguistics, 16(1), 15-34.

Bromley, K. (2007). Nine things every teacher should know about words and vocabulary instruction. Journal of Adolesent and Adult Literacy, 50(7), 528-538.

Bueno Gónzalez, A. (1998). True and false friends: Making the most of vocabulary acquisition. GRETA, 6(1), 23-27.

Chen, H. (1998). Second language vocabulary learning strategies: A preliminary investigation of Chinese EFL learners. The Proceedings of Seventh International Symposium on English Teaching (pp. 219-230). Taipei: Crane.

Chern, C. I. (1995). Chinese students' word-solving strategies in reading in English. In T. Huckin, M. Haynes, \& J. Coady (Eds.), Second Language Reading and Vocabulary Learning (2nd ed., pp. 67-85). Norwood, NJ: Ablex Publishing Corporation.

Coady, J. (1979). A psycholinguistic model of the ESL reader. In R. Machay, B. Barkman, \& R. R. Jordan (Eds.), Reading in a Second Language (pp. 5-12). Rowley, MA: Newbury House.

Coady, J. (1995). Research on ESL/EFL vocabulary acquisition: Putting it in context. In T. Huchin, M. Haynes, \& J. Coady (Eds.), Second Language Reading and Vocabulary Learning (2nd ed., pp. 3-23). Norwood, NJ: Ablex Publishing Corporation.

Cook, V. (2001). Second Language Learning and Language Teaching (3rd ed.). London: Arnold Publishers.

Edwards, L. (2009). How to teach Vocabulary. Pearson Education. Retrieved May 30, 2013, from http://pearsonlongman.com.htm

Greene, B. E., \& Lynch-Brown, C. (2002). Effect of teachers' reading aloud style on vocabulary acquisition and comprehension of students in the early elementary grades. Journal of Educational Psychology, 94, 465-474.

Greenwood, S. (2004). Content matters: Building vocabulary and conceptual understanding in the subject areas. Middle School Journal, 35(3), 27-34.

Hamada, M. (2009). Development of L2 word-meaning inference while reading. System, 37(3), 447-460.

Harman, J. (1999). Initial encounters with unfamiliar words in independent reading. Research in the Teaching of English, 33(3), 304-338.

Haynes, M., \& Baker, I. (1993). American and Chinese readers learning from lexical familiarization in English text. In T. Huchin, M. Haynes, \& J. Coady (Eds.), Second Language Reading and Vocabulary Learning (2nd ed., pp. 130-152). Norwood, NJ: Ablex Publishing Corporation.

Haynes, M., \& Bloch, J. (1995). Patterns and perils of guessing in second language reading. In T. Huchin, M. Haynes, \& J. Coady (Eds.), Second Language Reading and Vocabulary Learning (2nd ed., pp. 46-62). Norwood, NJ: Ablex Publishing Corporation.

Heilman, A. W., Blair, T. R., \& Rupley, W. H. (1998). Principles and Practices of Teaching Reading (8th ed.). Columbus, OH: Merrill.

Irvin, J. (1990). Vocabulary Knowledge: Guidelines for Instruction. Washington, DC: National Education Association.

Kaivanpanah, S., \& Alavi, M. (2008). Deriving Unknown Word Meaning From Context: Is it Reliable? RELC Journal, 39(1), 77-95. 
Kindle, K. J. (2009). Vocabulary Development during Read-Alouds. Primary Reading Teacher, 63(3), 202-211.

Laufer, B. (1992). How much lexis is necessary for reading comprehension? In P. J. L. Arnand, \& H. Bejoint (Eds.), Vocabulary and Applied Linguistics (pp. 126-132). London: MacMillan Academic and Professional Ltd.

Laufer, B. (1997). The lexical plight in second language reading: Words you don't know, words you think you know, and words you can't guess. In J. Coady, \& T. Huckin (Eds.), Second Language Vocabulary Acquisition (pp. 20-34). New York: Cambridge University Press.

Leikin, B., \& Deacon, H. (2007). Approaches to teaching children new words. Literacy Today, 1, 23.

Mart, Ç. (2012). Guessing the Meanings of Words from Context: Why and How. International Journal of Applied Linguistics \& English Literature, 1(6), 177-181.

McCollin, M., O’Shea, D., \& McQuiston, K. (2010). Improving Vocabulary and Comprehension Skills of Secondary-Level Students from Diverse Backgrounds. Preventing School Failure, 54(2), 133-136.

Morrison, L. (1996). Talking about words: A study of French as a second language learners' lexical inferencing procedures. The Canadian Modern Language Review, 53(1), 41-71.

Nash, H., \& Snowling, M. (2006). Teaching new words to children with poor existing vocabulary knowledge: A controlled evaluation of definition and context methods. International Journal of Language and Communication Disorders, 41(3), 335-354.

Nation, P. (1993). Vocabulary size, growth, and use. In R. Schreuder, \& B. Weltens (Eds.), The Bilingual Lexicon (pp. 115-134). Philadelphia, PA: John Benjamins Publishing Company.

Pierce, M. E., \& Fontaine, L. M. (2009). Designing Vocabulary Instruction in Mathematics. Reading Teacher, 63(3), 239-243.

Ridgway, T. (1997). Thresholds of the background knowledge effect in foreign language reading. Reading in a Foreign Language, 11(1), 151-168.

Samuels, S. J. (2002). Reading fluency: Its development and assessment. In A. E. Farstrup, \& S. J. Samuels (Eds.), What Research Has to Say about Reading Instruction (3rd ed., pp. 166-183). Newark, DE: International Reading Association.

Scott, F. (2001). World of Language. Upper Saddle River, NJ: Pearson.

Smith, C. B. (Ed.) (2003). Successful Techniques of Vocabulary. ERIC Topical Bibliography and Commentary.

Thornbury, S. (2002). How to Teach Vocabulary. Harlow: Longman.

Thornbury, S. (2006). Teaching Vocabulary Using Short Texts. In P. Robertson, \& R. Nunn (Eds.), The Study of Second Language Acquisition in the Asian Context (pp. 322-328). Seoul: Asian EFL Journal Press.

Thu, T. H. (2009). Learning Strategies Used by Successful Language Learners (p. 60). Online Submission.

Townsend, D., \& Collins, P. (2009). Academic Vocabulary and Middle School English Learners: An Intervention Study. Reading and Writing: An Interdisciplinary Journal, 22(9), 993-1019.

Visnga, P. T. (2008). Vocabulary Learning Strategies and Foreign Language Acquisition. Clevedon: Multilingual Matters.

Walters, J. (2009). The effect of keeping vocabulary notebooks on vocabulary acquisition. Language Teaching Research, 13(4), 403-423.

\section{Copyrights}

Copyright for this article is retained by the author(s), with first publication rights granted to the journal.

This is an open-access article distributed under the terms and conditions of the Creative Commons Attribution license (http://creativecommons.org/licenses/by/3.0/). 